\title{
Drug rash induced by levothyroxine and oral desensitization
}

\author{
Sérgio Duarte Dortas Junior ${ }^{1,2^{*}}$, Franklin Moreira De Araujo ${ }^{1}$, Cintia Ribas Souza ${ }^{3}$, Eduardo Micmacher ${ }^{1,3}$, \\ Soloni Afra Pires Levy ${ }^{4}$, Augusto Tiaqui Abe ${ }^{2}$, Augusto Tiaqui Abe ${ }^{4}$, Alfeu Tavares França $a^{2,4}$ \\ From 3rd WAO International Scientific Conference (WISC) 2014 \\ Rio de Janeiro, Brazil. 6-9 December 2014
}

\section{Background}

Synthetic Thyroxine (T4) is the treatment of choice for the correction of hypothyroidism.

\section{Methods}

We report a case of drug rash induced by levothyroxine and currently oral desensitization.

A 31 year-old woman had been diagnosed as Hashimoto's Thyroiditis. She was having levothyroxine for 9 years when she begun to present bilateral eyelids maculopapular rash. Blood exams and physical examination were normal except for the eyelids' rash.

As she stopped using levothyroxine, the rash has disappeared.

Her endocrinologist prescribed her other brands of levothyroxine, and the patient reported the same reaction.

\section{Results}

Therefore, we performed an oral desensitization with multiple doses of the drug preparation. The procedure was started at a dose of $1,00 \mu \mathrm{g}$. Every 30 minutes the dose was increased until a total dose of $127,00 \mu \mathrm{g}$.

After 2 months, she currently tolerates $100,00 \mu \mathrm{g} / \mathrm{d}$.

\section{Conclusions}

It is unusual that biological substances induce allergic reactions when given exogenously.

Once it happens, drug desensitization can be performed at a hospital by experienced professionals with satisfactory response.

\section{Consent}

Written informed consent was obtained from the patient for publication of this abstract and any accompanying

${ }^{1}$ Universidade Iguaçu, Brazil

Full list of author information is available at the end of the article images. A copy of the written consent is available for review by the Editor of this journal.

\section{Authors' details}

${ }^{1}$ Universidade Iguaçu, Brazil. ${ }^{2}$ Hospital Universitário Clementino Fraga Filho Hucff-Ufrj, Brazil. ${ }^{3}$ Hospital Geral De Nova Iguaçu, Brazil. ${ }^{4}$ Hospital São

Zacharias, Brazil.

Published: 8 April 2015

doi:10.1186/1939-4551-8-S1-A21

Cite this article as: Dortas et al:: Drug rash induced by levothyroxine

and oral desensitization. World Allergy Organization Journal 2015

8(Suppl 1):A21.
Submit your next manuscript to BioMed Central and take full advantage of:

- Convenient online submission

- Thorough peer review

- No space constraints or color figure charges

- Immediate publication on acceptance

- Inclusion in PubMed, CAS, Scopus and Google Scholar

- Research which is freely available for redistribution
() Biomed Central 